\title{
COMPARISON OF LITERACY STATUS OF VILLAGE KALIMAGRI WITH THE AVERAGE LITERACY RATE OF UDAIPUR: SOCIO- ECONOMIC SURVEY OF VILLAGE IN UDAIPUR
}

\author{
Sukriti Sharma \\ MSC. In Geography
}

\begin{abstract}
In the modern era of rapid globalization and economic and social transformation, the society is changing economically as well as socially. The transformation is both ways i.e. positive and negative, to study the literacy status in rural society particularly in the district like Udaipur where the literacy rate is commendable and higher than the country's average literacy rate. A village survey was conducted in Kali-Magri village in Salumbar tehsil of Udaipur. Here the rural - urban differential in literacy is negatively correlated. There is a lot of difference in literacy status between Udaipur and the village. These differences show that the educational development is one way and not the whole.
\end{abstract}

Keywords- Literacy, Rural areas, Udaipur, Village, Differences, Kali-Magri, Development

\section{INTRODUCTION}

Education is the most empowering force in the world. It creates knowledge, builds confidence, \& breaks down barriers to opportunity. Malala, the true example of Women Empowerment once said "In some parts of the world, students are going to School every day. It's their normal life. But in other parts of the world; we are starving for education like a precious gift. It's like a diamond," In early censuses up to 1981 , it was necessitates to work out on literacy rate taking into account the total population. So in this paper I want to highlight educational status of a village named Kalimagri, in Salumbar (Udaipur). It is a medium sized village, where the average literacy rate is $39.15 \%$. On the other hand Udaipur is rising as an educational hub with 5 Universities, 14 Colleges and 160 high Schools. Udaipur is selected as a fifth best management institution in the country according to NIRF ranking released by MHRD. The picture is clear that the development of education is not over all complete because the villages like Kalimagri are deprived of such rightful chances of education. The average literacy rate of the district is $90.43 \%$, which is commendable but is this a complete education development of the district?

\section{DATA AND METHODOLOGY}

The data which has been collected for the study includes the demography, social structure, infrastructure facilities, village economy, village administration, resource availability and all the major aspects of a socio-economic study. The following techniques and methods have been taken into use during the field excursion:

Sources of data: The required data was collected from both primary and secondary. The primary data was collected from direct interaction with the villagers, photographs, layout maps and sketches. During the household segment, the information was extracted either from the head of the family or the more responsive and interactive member of the family. On the other hand the secondary sources are the websites looked into in order to gather the prior information and the related literature. Both qualitative and quantitative methods were used.

The two major techniques which proved useful in my study are:

- Questionnaire: A questionnaire is a set of questions especially designed to facilitate the objectives of the survey. An interviewer assists the respondent to complete the questionnaire. The interview is conducted in person, usually at the respondents' residence or place of work. When paper based, this method is called Paper and Pencil Interviewing (PAPI).

- Direct Observation: This method consists of observing and measuring directly the characteristics of interest in the field. Direct measurement is usually precise and 
when observations only are made there is no response burden. These observations with aids like photography, sketching, audio visual, recording etc. and just in the form of notes are valuable source of nonquantifiable information to validate different points of view and to draw conclusions. The main advantage of direct observation is that an event, institution, facility, or process can be studied in its natural setting, thereby providing a richer understanding of the subject.

\section{OBJECTIVES}

- To highlight the educational status in village

- To show the difference between village's literacy rate and the district's education system

\section{STUDY AREA}

Kalimagri is a medium size village located in Salumbar tehsil of Udaipur district, Rajasthan with total population of 8162 of which 4298 are males and 3873 are females as per 2018 survey report. Majority of the people are followers of Hinduism constituting a percentage of 92 . Whereas there are 8per cent of population comprises of Muslims. There were three types of houses, Kuccha, Pucca and Semi Pucca covering percentages of 5per cent, 57per cent and 38per cent respectively. Gram Panchayats are the local political units of rural areas. They monitor the infrastructure and the decision making of the village lie in their hands. The village has its own Anganwadi Centre. It provides facilities like supplementary nutrition, non-formal preschool education and nutrition and health education.

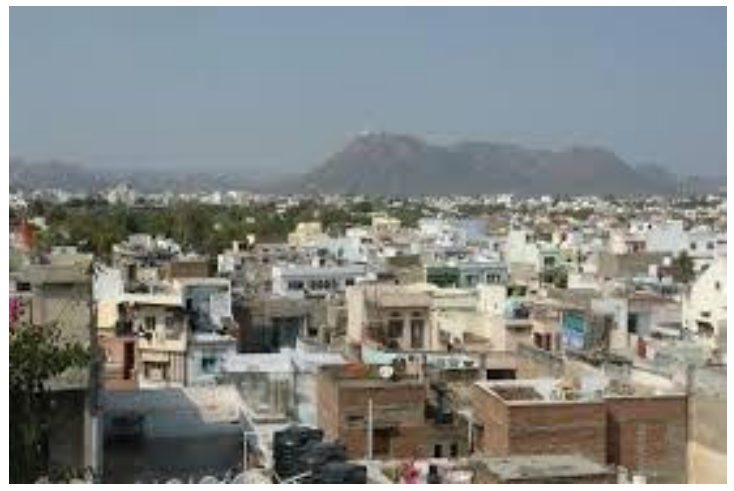

Figure 1- view of Kali-Magri houses

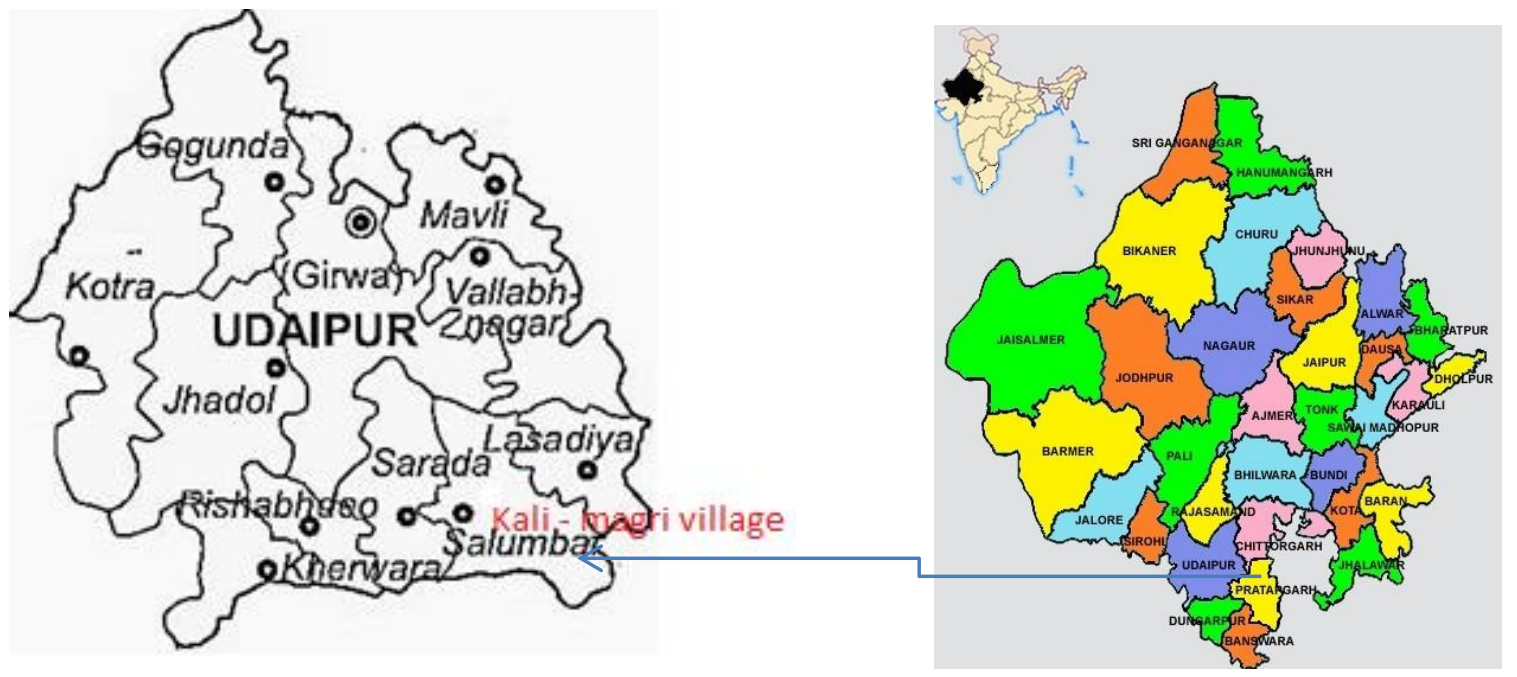

Figure 2 - Map of Udaipur, Salumbar district, Kali-Magri village 


\section{International Journal of Engineering Applied Sciences and Technology, 2020 \\ Vol. 5, Issue 1, ISSN No. 2455-2143, Pages 204-208 \\ Published Online May 2020 in IJEAST (http://www.ijeast.com)}

Table-1: Demographic structure of village (2018) survey

\begin{tabular}{|l|l|l|}
\hline Education Level & $\begin{array}{l}\text { No. of } \\
\text { Persons }\end{array}$ & $\begin{array}{l}\text { \% to Total } \\
\text { Population }\end{array}$ \\
\hline Below matric & 2480 & 30.38 \\
\hline Matric & 1000 & 12.25 \\
\hline $10+2$ & 500 & 6.12 \\
\hline U.G. & 65 & 0.79 \\
\hline P.G. & 16 & 0.19 \\
\hline Phd. & 1 & 0.01 \\
\hline Uneducated & 1000 & 12.2 \\
\hline 0-7 years (Age & 3100 & 37.9 \\
\hline Group) & & \\
\hline
\end{tabular}

Table-2: Demographic structure of village (2011)

\begin{tabular}{|l|l|}
\hline Population & Total \\
\hline Total persons & 758 \\
\hline Males & 382 \\
\hline Females & 376 \\
\hline Schedule Caste & $0.0 \%$ \\
\hline Scheduled Tribe & $99.7 \%$ \\
\hline
\end{tabular}

The village covers an area of 7,656 hectares and is home to 1,427 households. The total population of the village is 8,162 among these 4,289 are males and 3,873 are females.

\section{LITERACY STATUS IN VILLAGE}

The Salumbar tehsil of Udaipur consists of 268 revenue villages which are organized in 46 gram Panchayats and one town. The village which has been chosen for survey was Kali- magri which is located $63 \mathrm{~km}$ towards south from district headquarters Udaipur, $14 \mathrm{~km}$ from Salumbar and $409 \mathrm{~km}$ from the state capital. Literacy and level of education are basic indicators of the level of development. The village comprises of 5140 literates with 3072 males and 2068 females separately. The working population is 2295 workers. There are 5 colleges and 4 schools near village but not in the village. Children have to travel some distances to reach at their station. There is availability of local transportation and buses at the distance of $9.4 \mathrm{~km}$ from the village. Here the main obstacle of education is the distance, which creates problems and puts them behind. Spread and diffusion of literacy must be required in the village. For active participation in education there should be an availability of well-furnished schools and colleges in village.

Table - 3: Literacy level among population during survey in 2018

\begin{tabular}{|l|l|l|l|}
\hline Population & Total & $\begin{array}{l}\text { Schedule } \\
\text { caste }\end{array}$ & $\begin{array}{l}\text { Scheduled } \\
\text { tribe }\end{array}$ \\
\hline $\begin{array}{l}\text { Total } \\
\text { persons }\end{array}$ & 8162 & 2777 & 4 \\
\hline Males & 4289 & 1452 & 1 \\
\hline Females & 3873 & 1325 & 3 \\
\hline
\end{tabular}

\section{WOMEN'S CONDITION IN VILLAGE}

\section{Neglecting female literacy:}

The village comprises of 5140 literates with 3072 males and 2068 females separately. The working population is 2295 workers. It shows that the peoples of the village are mostly not in the favour of female literacy. When I surveyed in the village most of the girls said that they take out of schools to share the family responsibilities. But there were also some people those prefer girl's literacy as essential as male's literacy. Some girls are forced by the families to learn work of home and never be encouraged for studies. Mostly the mentalities of the villagers were that the male child is their investment and girls are burden. Here are some of the reasons that will know why female literacy is neglecting in villages:

1. Poverty

2. Dowry system

3. Male dominance society

4. Early marriage

5. Priority of son's education (as investment)

6. Poor surroundings for girls in schools

\section{Women's occupation:}

Women's Engagement in the fields is very high. 83per cent of the households replied that the 
women of the family work in fields. It is undoubtedly one of the prime reasons behind underemployment in the sector of agriculture. The number of people employed is more than the requirement of labour. Government needs to work towards this.

\section{WHY VILLAGES ARE LESS PREFFERED COMPARED TO THE CITIES:}

In villages only few areas have good facility for schooling of children. Not only education other basic amenities like - medical facilities, public transportation, employment, etc. are major factors for preferring cities over village. Because of these disparities people migrate from their place of origin for better standard of living. The young pupils of villages migrate because city offers them better schools, colleges, universities. Government and private organizations have stressed on the mobilization of resources and developing the required facilities, but not much has been achieved so far. There are some barriers in rural areas to highlight:

- Difference in socio - economic conditions

- Less qualified teachers

- Expensive studies in city (lack of financial resources)

- Poor infrastructure

- Less wages

We can reduce the migration towards urban areas by improving the above mentioned facilities. Governments as well as the reputed people of the villages will take the initiative to improve the picture of rural areas to overcome these disparities.

\section{CONCLUSION}

Literacy is essential for social and human development and provides individual the skills and empowers them to transform their lives. The study and survey brings out the problems of villagers and villages like- village have poor connectivity from one place to another and that is often one of the main reason why the literacy in villages are worse than the cities. Over one - third of Indian population living in rural areas is illiterate even after 71 years of independence according to the census. Literacy is an essential tool for individuals and states to be competitive in the new global knowledge economy. The India's urban and rural population percentages are $17.1 \%$ and $67.2 \%$ respectively, it shows that rural population is more than the urban's, but still they are behind in literacy due to their migration in cities because they get facilities that are not available here. As same as the situation in Kali-magri village too, where children or reputed families migrate to cities for better opportunities and that's the main reason why rural areas are still behind the urban areas. There are some suggestions to upgrade the rural education in villages are:

1. Encourage free education

2. Establish schools and colleges in village, then children will not have to cover distance for study

3. Suitable and clean infrastructure in schools and colleges for girls child especially

4. Adequate number of teachers

5. Introduce new technical skills in students

6. Remove the digital gap in rural and urban societies (computer skills)

\section{REFERENCES}

1. India rural - urban differentials in literacy shodhganga

a. https://shodhganga.inflibnet.ac.in

2. Fitzwygram, R.J. Hints for the improvement of village schools and the introduction of industrial work, second edition, revised and enlarged

3. Ratmaningsih, N., Logayah, D.S., Afidah, N.N., Abdulkarim, A. (2019). Literacy village: A breakthrough in creating a Literate culture, 10P Conf. Series : Earth and Environment Science 286

4. Singh, C.K. (2015). Womens Literacy in India - issues and Challenges, Global Journal of Interdisciplinary Social Sciences

5. Dutt, K.G. (2017). The Rule of Adult Literacy in Transforming the Lines of Women in Rural India : Overcoming Gender Inequalities, Comparative case studies in Bhilwara District Rajasthan and Howrah District West Bengal India

6. Ramadani, I. et. al. (2011). Extention of Urban Infrastructure in the Village of Kosovo, The $2^{\text {nd }}$ International Geography Symposium

7. Green, David, A. and Riddle, C. (2007). Literacy and the Labour Market: The Generation of Literacy and its Impact on Earnings for Native Born Canadians, International Adult Literacy Survey

8. www.shemford.com, Education in Cities and Villages of India

9. www.onefivenine.com

10. https://villageinfo.in Indian village directory

11. Kumar, J. (2014). Progress of urban literacy in India : Focus on Metropolises, ISSN : 0972 7388 (pp 1-2)

12. Dr. Kaur, S. (2014). Literacy rate and educational level in India : A Comparison 
Based on NSSO Estimates, volume: 3, Issue: 5

13. Archakis, A. and Tsakona, V. (2013). Sociocultural diversity, identities and critical education : Comparing conversational narratives at school (pp 2-3)

14. Vallaster, C. (2005). Cultural Diversity and its Impact on Social Interactive Processes: Implications from an Empirical Study, http://doi.org/10.1177/1470595805054490

15. District Handbook (2016).

16. Kothari, C.R. (2019). Research Methodology Methods and Techniques, $4^{\text {th }}$ Edition New Age International Publisher, ISBN 10 9386649225, ISBN 13 - 978-9386649225 (pp 2-25)

17. http://www.mapsofindia.com/villages/Rajasth an/kalimagri.html

\section{ACKNOWLEDGEMENT}

This paper was accomplished by the proper guidance of my Govt. P.G. College professors and my guide Mr D.K. Sharma who encouraged and developed my skills in this research work. I am highly gratitude for having such a support and overwhelming guidance. I also thanked my parents for believing in me and motivate me to keep going in research work. 